\title{
TUMOUR CASE IN KOI CARP (Cyprinus carpio)
}

\author{
Lili Sholichah")\#, Angela Mariana Lusiastuti**), Domenico Caruso***), \\ I Wayan Subamia*****), and Uni Purwaningsih ${ }^{* *}$ \\ "Research Institute for Ornamental Fish Aquaculture \\ *) Research Institute for Freshwater Aquaculture, Bogor \\ ${ }^{* * *}$ Institute de Recherche pour le Developpement, France \\ Research Institute for Fish Breeding and Aquaculture, Sukamandi, West Java
}

(Received 12 July 2010; Accepted 26 November 2010)

\begin{abstract}
A case study of tumour in Koi Carp (Cyprinus carpio) was observed in rearing periode. This tumour occurs solitary, large, pale red, fleshy masses under the lips and dental plates on the outside, and by reason of its size, may prevent closure the mouth. Moreover, this tumour goes through into the inside of the mouth. At necropsy, there were two soft, firm, small mass at inside of the mouth and the bigger mass at outside the mouth. Samples of this tumour were fixed in $10 \%$ formalin were used for histology analysis. The clinical course of the tumour is one of relatively slow but progressive growth. The proliferative stage of the neoplastic process is preceded and accompanied by a striking vascular reaction. Intensed hyperemia invariably occurs in that region of the mucosal surface which later becomes the site of neoplastic proliferation. Neoplastic cells lied around lamina propria and submucosal. These cells were joined together to make vacuolization and the other cells become pleiomorphism with hyperchromatic nucleus and N/C ratio cells are $1: 1$. In some area, there were many empty holes, around the holes there were debris cells, inflammation cells, and erythrocytes.
\end{abstract}

KEYWORDS: tumour, Koi, neoplastic cells

\section{INTRODUCTION}

Koi are ornamental domesticated varieties of the common carp (Cyprinus carpio) that are kept for decorative purposes in an outdoor Koi pond or water gardens. They are also called Japanese carp which are still popular as a symbol of love and friendship. A variety of color and its pattern have been developed; common colors include white, black, red, yellow, blue, and cream. The most popular category of Koi is the Gosanke, which is made up of the Kohaku, Taisho Sanshoku, and Showa Sanshoku variet- ies. Koi are cold-water fish, but benefit from being kept in the $15^{\circ} \mathrm{C}-25^{\circ} \mathrm{C}\left(59-77^{\circ} \mathrm{F}\right)$ range and do not react well to long cold winter temperatures, their immune system turns off below $10^{\circ} \mathrm{C}$. Koi ponds usually have a meter depth or more in areas of the world that become warm during the summer, whereas in areas that have harsher winters, ponds generally have a minimum of 1.5 meters ( $4 \frac{1}{2}$ feet).

Fish, like mammals, are frequently affected by neoplastic proliferations. Those neoplasms are classified according to mammalian tumour

\# Corresponding author. Research Institute for Ornamental Fish Aquaculture, Jl. Perikanan No.13, Depok 41152, Indonesia. Tel.: + 62217520482

E-mail address: lili.bihatdepok@gmail.com 
classifications. The neoplasms of the gills are very rare, and few published cases include papillomas, squamous cell carcinomas, fibromas, chondromas, and branchioblastomas. The term branchioblastoma refers to a neoplastic proliferation of primitive, blast-like branchial cells with the capacity to differentiate into epithelial and mesenchymal cells. Based on its macroscopic and histologic growth characteristics, this tumour is considered benign. Its locally expansive growth.

Tumour formation is normally associated with an increased in mitotic rate and less degree of differentiation of the constituent cells. While still part of the body, depending on its blood supply and supporting stroma of connective tissue, the cells appear unresponsive to the normal controls of proliferation for the cell of their type. Tumours can arise from virtually any tissue of the body. Only the adult neuron, which is incapable of division, appears to be refractory.

The aetiology of tumours is generally complex and many of the factors which contribute to tumour initiation and growth remain unknown. Evidence supports of a multiplicity causes in mammalian tumours differ in this respect. Known and suspected factors contributing to tumours formation in fish include viruses, chemical or biological toxins, physical agents, hormones, and the age, sex, genetic predisposition and immunological competence of the host. A genetic link may be closely associated with geographical location, which in turn may facilitate transmission of an infectious agent or aid the effects of carcinogenic chemical.

Epizootic of external neoplasms, such as skin and lip papillomas, has been observed in fish from the Great Lakes (Harshbarger \& Clark, 1990). Lip and body papillomas are the most common forms of neoplasia observed in white sucker, Catostomus commersoni, from the Great Lakes basin (Smith \& Zajdlik, 1987)

Although there is some evidence that high prevalences of external tumours in benthic fish are linked to exposure to chemical contaminants (Bowser et al., 1991; Premdas et al., 1995), external tumours are also found on fish from relatively uncontaminated regions (Roberts \& Bullock, 1979).

\section{METHODOLOGY}

This is a case study, which is not based on sampling. The discussion is based on the maintenance in the initial conditions, clinical symptoms, possible causes, type of tumour and how to prevent it. Due to therapy is very difficult and unprofitable because fish will die.

\section{Fish Rearing}

Koi fishes were reared in backyard pond and feed with worms (Lumbricus terrestris) and commercial pellet in the morning and afternoon at 8 a.m. and 4 p.m. Koi fish hatchery activities was conducted at the Ornamental Fish Culture Research Institute, Depok by using four types of ponds which are broodstock pond, spawning pond, then nursery pond, and rearing pond.

The incidence of tumours in Koi fish are found in the rearing ponds at the time fish were moved to other places (pool display). There was only one occurrence of the tumour in 400 fishes of 4-month-old Koi fish with a body length of $17-21 \mathrm{~cm}$. Fish that exposed to a tumour in the mouth is directly taken and separated by other healthy fish. Clinically the fish become slow and would not eat.

There are two mass inoculation of the tumours in the fish, which is outside and inside of the mouth attached. The tumour size on the outside of the fish's mouth is bigger than that inside of the mouth fish. Subsequently performed minor surgery was done to remove tumour mass from the mouth of the fish. As a result of bleeding from the tumour and postoperative activity can not be stopped so that the resulting weakened condition of the fish and finally a few moments later the fish died.

Tumour mass was successfully removed subsequently prepared for histology test network.

\section{Clinical Signs}

Top Swimming. It is distinguished from swimming at the top to interact with the owner or to feed. This is particularly abnormal if the fish is breathing at the top or trying to gulp air (also called piping), or are hanging around a water fall as the source of oxygen. This can happen to one or several fish, and is particu- 
larly significant when the entire school or group of fish are at the top (especially in the early morning hours just prior to dawn), or are staying near an air stone or aerator.

Swimming on one side, upside down, or unable to go to the bottom or top without a struggle. Koi are normally able to move up and down effortlessly in the water column, so that a fish which has difficulty doing this is not behaving normally. Suspect of gas bladder problems can be many causes, three corrections of swim bladder problems are rarely possible. Even if the cause can be identified and eliminated, the gas bladder can form scars, and scars in the gas bladder will not resolve. Balance, neurological dysfunctions, vitamin deficiency, and injury can also cause abnormal swimming.

There were masses found under the lips and dental plates on the outside, and another masses goes through into the inside of the mouth. The colour of the tumour was generally white-reddish in the outside and inside the mouth even the consistencies of the tumour were compact and their surfaces were generally smooth.

\section{Water Quality Management}

Water used to mantain the parent directly derived from irrigation without any treatment in advance. quality management are also discussed here, only to show that water quality does not play a role in the formation of tumours in the case of Koi fish. Water used to maintain the parent directly derived from irrigation without any treatment in advance. Irrigation water is also used for farming and livestock. Conditions in the pond water, especially water depth and smoothness of the inlet and outlet channels are controlled at feeding time in the morning and afternoon. During the dry season, in the morning the inlet was closed and opened in the afternoon to keep the oxygen supply. It is done in accordance with the conditions overgrown pond that many aquatic plants, so at that night, the competition between fish of oxygen occurs with the water plant that grows in ponds and waterways, which was opened is expected to help supply the oxygen in the ponds. While the supply of oxygen during the day fulfilled from the water plant photosynthesis and diffusion of oxygen from the air.

When moss (algae filament) and water plant in the pond began to cover the surface, then do the cleaning algae and aquatic plants so that is not as to block the light, oxygen diffusion, and reduce competition. This cleaning is done by lifting the moss and water plants to the embankment.

\section{Histological Examination}

Koi showed clinical sign of tumour infection was necropted. The samples for histopathological examination were prepared from tumour mass outside and inside mouth then preserved in 10\% Neutral Buffer Formalin (NBF). Histopatological processing followed to Gurr Method (1956) there are consist of fixation, cleaning, embedding, cutting, and staining with hematoxylin and eosin. The tumours were minimum fixation in $10 \%$ NBF not less from 24 $\mathrm{h}$. The tumours were cutting into 3-5 $\mathrm{mm}$ and $1 \times 1 \mathrm{~cm}$ thickness, later tumours were dehydrated using an ascending ethanol series, cleared in xylene and infiltrated with paraffin. The tumours were embedding in paraffin and sectioned at 3-5 $\mu \mathrm{m}$ thickness. After dewaxing, tissue section was stained with Hematoxyline and Eosin (HE) for routine examination. Futhermore, the preparation of tumour slide was observed with microscope to know alteration that was happened in $20 x$ magnification.

\section{RESULTS AND DISCUSSION}

Tumours are classified (Tabel 1) on a histopathological basis, according to the cell or tissue of origin (this is known as the tumours histogenesis). In the more anaplastic tumours, the cells are difficult to identify and this is complicated further when a combination of tissues occurs. Since the terminology used in classification is based on the tumours in human being, the terms 'benign' and 'malignant' persist to designate certain cell patterns. There is no hard and fast line of demarcation to separate the two types; it depends on the experience of the individual pathologist.

On fish specimens affected tumour cases, the history of the tumour is rarely known, it is also important to note that determining whether the tumour is malignant or vice versa.

Macroscopically, this tumour occur solitary, large, pale red, fleshy masses under the lips and dental plates on the outside, and by reason of its size, may prevent closure the mouth. Moreover, this tumour goes through into the inside of the mouth. At necropsy, there were two soft, firm masses, small mass at in- 
Tabel 1. Classification on of tumours")

\begin{tabular}{|c|c|c|}
\hline Tissue & Benign & Malignant \\
\hline Epithelial & $\begin{array}{c}\text { Papilloma } \\
\text { papillary folder } \\
\text { squamous cell } \\
\text { basal cell } \\
\text { odontoma, adamantinoma } \\
\text { Adenoma } \\
\text { gland-like } \\
\text { duct-like }\end{array}$ & $\begin{array}{c}\text { Carcinoma } \\
\text { Epithelioma } \\
\text { epidermoid c arc inoma }\end{array}$ \\
\hline \multirow{2}{*}{$\begin{array}{c}\text { Mesenchymal } \\
\text { Non-hae motopoietic }\end{array}$} & & \\
\hline & $\begin{array}{c}\text { Fibroma (fibrous connective tissue) } \\
\text { Leiornyoma (smooth muscle) } \\
\text { Rhabdormy oma (striated muscle) } \\
\text { Lipoma (fat) } \\
\text { Chondroma (cartilage) } \\
\text { Osteoma (bone) }\end{array}$ & $\begin{array}{c}\text { Sarc oma (undiffe rentiated) } \\
\text { Fibrosarc oma } \\
\text { Leiomy osarc oma } \\
\text { Liposarc oma } \\
\text { Chondrosarc oma } \\
\text { Osteosarc oma }\end{array}$ \\
\hline Hae matopoietic & Lymphoma & $\begin{array}{l}\text { Malignant lymphoma } \\
\text { Lymphosarc oma }\end{array}$ \\
\hline Neural (nerve cell) & $\begin{array}{c}\text { Neuroma } \\
\text { Neurolemmoma } \\
\text { Ganglioneuroma }\end{array}$ & \\
\hline $\begin{array}{l}\text { Pigment } \\
\text { Embryonal }\end{array}$ & $\begin{array}{c}\text { Melanoma } \\
\text { Teratoma } \\
\text { Nephroblastoma }\end{array}$ & Malignant melanoma \\
\hline
\end{tabular}

* Modified from Mawdeslay-Thomas (1974)

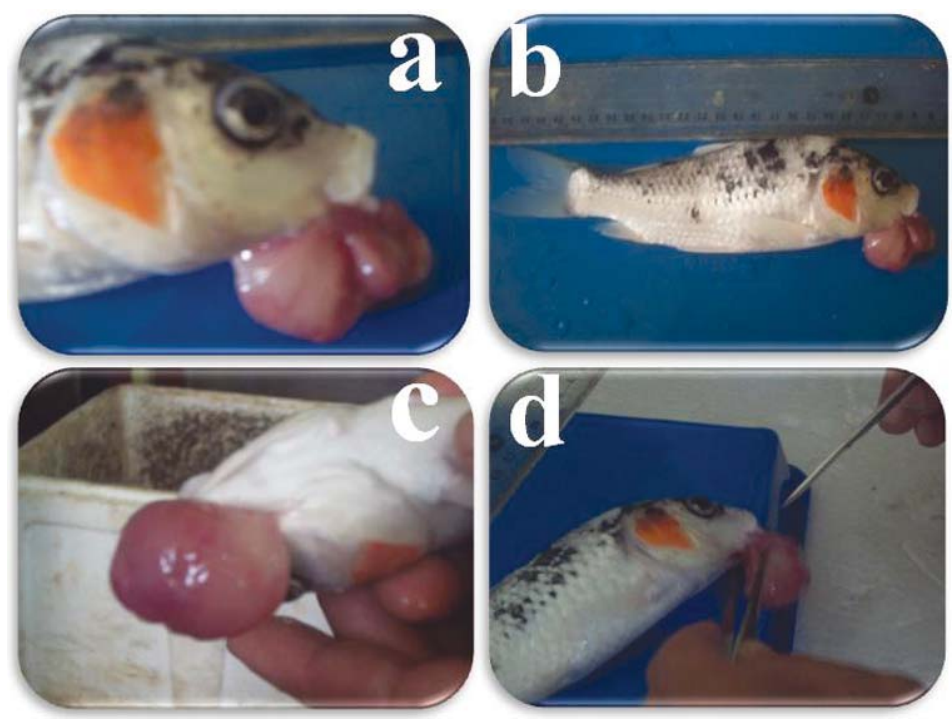

a. Front view of tumour, b. Side view of tumour, c. Total length of infected fish, d. Preparation for minor surgery

Figure 1. Koi with tumours 
side the mouth and the bigger mass at outside the mouth (Figure 1).

The clinical cause of the tumour is one of relatively slow but progressive growth. The proliferative stage of the neoplastic process is preceded and accompanied by a striking vascular reaction. Intensed hyperemia invariably occurs in that region of the mucosal surface which later becomes the site of neoplastic proliferation. Neoplastic cells lied around lamina propria and submucosal. These cells were joined together to make vacuolization and the other cells become pleiomorphism with hyperchromatic nucleus and N/C ratio cells are $1: 1$. In some area, there were many empty holes, around the holes there were debris cells, inflammation cells and erythrocytes.

Based on these histo morphology characteristics, tumour was diagnosed as branchioblastoma. This neoplasm is rarely reported in fish. Spontaneously occurring branchioblastomas have been described in rainbow trout (Oncorhynchus mykiss) and brown trout (Salmo trutta) and one koi carp (Wildgoose, 1992). In contrast, Bond, (1996) that case described here had well-demarcated, neoplastic masses originating from the mandibular arch, respectively. The pseudo branch is a remnant of the mandibular arch. The tumour could not be included in the classification of tumours in Table 1, because not listed in it. Classification of tumours in Table 1 is the classification that occurs in humans. The clas- sification of tumours in fish is not yet exist. In fish, neoplasms are frequently reported to be chemically inducible. Branchioblastomas can be experimentally induced by exposure to carcinogens, such as N-methyl-N'-nitro-Nnitrosoguanidine and nifurpirinol, in Medaka (Oryzias latipes), sunshine bass (Morone saxatilis $\times$ Morone chrysops), Japanese Medaka (Oryzias latipes), Channel Catfish (Ictalurus punctatus) and Platyfish cross-swordtail F1 hybrids (Xiphorus maculates cross helleri) (Chen et al., 1996; Thiyagarajah et al., 2001). Formaldehyde and malachite green are known tumour inducers in mammals (Fernandez et al., 1991; Srivastava et al., 2004). There are, however, these chemicals are usually used in ornamental fish.

The degree of differentiation of epithelial cells in the tumour varies, some being relatively normal and others greatly enlarged, with poorly stained or vacuolated cytoplasm, large, occasionally multiple nuclei, and prominent nucleoli. Mucous cells may be reduced in number or may be absent. There is a wide variation in form from tumours with only slight hyperplasia of the epithelium and a broad-based thickened dermis, to those which are truly papillary, having long finger-like projections of multiple layers of epithelial cells supported by a stroma of connective tissue (Carlisle \& Roberts, 1977).

Recurrent exposure of formaldehyde and malachite green are likely because they are
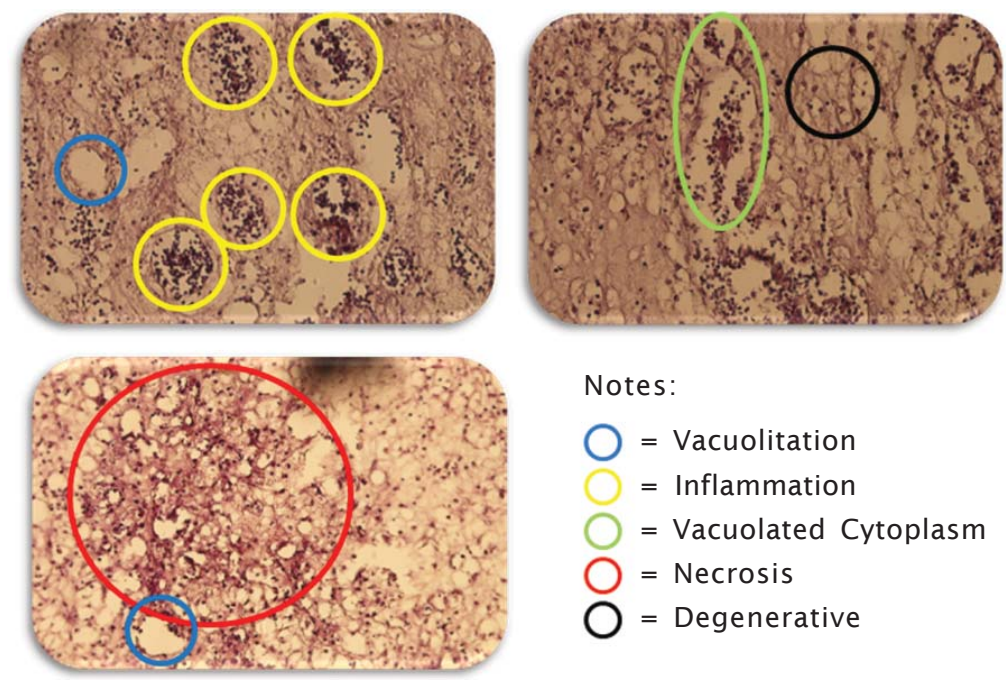

Notes:

$$
\begin{aligned}
& =\text { Vacuolitation } \\
& =\text { Inflammation } \\
& =\text { Vacuolated Cytoplasm } \\
& =\text { Necrosis } \\
\bigcirc & =\text { Degenerative }
\end{aligned}
$$

Figure 2. Histopathological of tumour in Koi (H\&E, 20x) 
Table 2. Water chemistry

\begin{tabular}{cc}
\hline Parameters & Ponds \\
\hline $\mathrm{pH}$ & $6,3-7,1$ \\
Temperature $\left({ }^{\circ} \mathrm{C}\right)$ & $19,0-28,0$ \\
$\mathrm{DO}(\mathrm{mg} / \mathrm{L})$ & $4,2-6,5$ \\
$\mathrm{CO}_{2}(\mathrm{mg} / \mathrm{L})$ & $2,9-6,4$ \\
$\mathrm{NO}_{2}(\mathrm{mg} / \mathrm{L})$ & $0,0650-0,1439$ \\
$\mathrm{NO}_{3}(\mathrm{mg} / \mathrm{L})$ & $0,0547-0,1164$ \\
$\mathrm{NH}_{3}(\mathrm{mg} / \mathrm{L})$ & $0,0913-0,1739$ \\
Hardness $(\mathrm{mg} \mathrm{CaCO}$ & $54,15-155,0$ \\
\hline
\end{tabular}

frequently used for prophylactic anti parasitic and antifungal treatments. Breeding and selection criteria for koi carp are mainly based on the external appearance, with less emphasis on health conditions. Therefore, genetic predispositions for the development of certain tumours are possible.

\section{Water Quality Analysis}

Water temperature during the dry season ranges between $19^{\circ} \mathrm{C}-28^{\circ} \mathrm{C}$ (Tabel 2). Fluctuations occur because of the hot afternoon air temperatures, while at night the temperature decreases.

\section{CONCLUSION}

Tumourwas diagnosed branchioblastoma nevertheless neoplasm is rarely reported in fish. If local invasion of tissues and metastases, as opposed to multiplicity of foci, are carefully noted and detailed gross and histopathological descriptions are recorded, a basis for further study and comparison is established without requiring the use of tumour nomenclature which can be confusing in the case of fish neoplasms.

\section{REFERENCES}

Bond, C.E. 1996. Circulation, respiration, and the gas bladder. In: Biology of Fishes Bond $C E$, ed. Saunders College Publishing, Fort Worth, TX, p.367-392.

Bowser, P.R., Wolfe, M.J., Reimer, J., \& Shane, B.S. 1991. Epizootic papillomas in brown bullheads, Ictalurus nebulosus from Silver Stream reservoir, New York. Dis. Aquat. Org., $11: 117-127$.
Carlisle, J.C. \& Roberts, R.J. 1977. An epidermal papilloma of the Atlantic salmon I: Epizootiology, pathology and immunology. J. Wild Dis., 13: 230-234.

Chen, H.C., Pan, I.J., Tu, W.J., Lin, W.H., Hong, C.C., \& Brittelli, M.R. 1996. Neoplastic response in Japanese medaka and channel catfish exposed to N-methyl-N'-nitro-Nnitrosoguanidine. Toxicol Pathol., 24:696706.

Fernandes, C., Lalitha, V.S., \& Rao, V.K. 1991. Enhancing effects of malachite green on the development of hepatic preneoplastic lesions induced by $\mathrm{N}$-nitrosodiethylamine in rats. Carcinogenesis, 12:839-845.

Gurr, E. 1956. A Practical Manual of Medical and Biological Staining Technique, Leonard Hill Ltd, London, 373 pp.

Harshbarger, J.C. \& Clark, J.B. 1990. Epizootiology of neoplasms in bony fish of North America. Sci. Total Environ., 94 : 1-32.

Mawdesley-Thomas, L.E. \& Newman, A.J. 1974. Some observations on spontaneously occurring tumours of the central nervous system of Sprague-Dawley derived rats. J. Pathol., Feb, 112(2):107-16.

Thiyagarajah, A., MacMillan, J.R., \& Munson, A.D. 2001. Neoplasms in cultured sunshine bass. J. Fish Dis., 24:551-556.

Wildgoose, W.H. 1992. Papilloma and squamous cell carcinoma in koi carp (Cyprinus carpio). Vet Rec., 130:153-157.

Premdas, P.D., Metcalfe, T.L., Bailey, M.E., \& Metcalfe, C.D. 1995. The prevalence and histological appearance of lip papillomas in white suckers (Catostomus commersoni) from two sites in central Ontario, Canada. J. Great Lakes Res., $21:$ 207-218. 
Roberts, R.J. \& Bullock, A.M. 1979. Papillomatosis in marine cultured rainbow trout Salmo gairdneri (Richardson). J. Fish. Dis., 2: 7577.

Smith, I.R. \& Zajdlik, B.A. 1987. Regression of epidermal papillomas affecting white suck- ers, Catostomus commersoni (Lacapede), from the Ontario, Canada. J. Fish Dis., 10 : 487-494.

Srivastava, S., Sinha, R., \& Roy, D. 2004. Toxicological effects of malachite green. Aquat Toxicol., 66:319-329. 